\title{
Apprising Energy Efficiency Projects and Relevance to ESCOs
}

\author{
Atik Sheikh ${ }^{1, *}$, Rahul Ravi ${ }^{2}$, Darshan Joshi ${ }^{3}$, Medha Joshi ${ }^{4}$ \\ ${ }^{1}$ Confederation of Indian Industry - Sohrabji Godrej Green Business Centre, India \\ ${ }^{2}$ ICF International, India \\ ${ }^{3}$ Mundra Solar Private Limited, India \\ ${ }^{4}$ National Institute of Construction Management and Research, India
}

Copyright $(2016$ by authors, all rights reserved. Authors agree that this article remains permanently open access under the terms of the Creative Commons Attribution License 4.0 International License

\begin{abstract}
Currently, India is facing an energy crisis and lots of efforts are being put in order to reduce this widening gap between energy demand and supply. One of the most cost effective ways of reducing this gap is by implementing Energy Efficiency (EE) projects. These projects have a very high potential in India as it is estimated that it can generate energy savings worth $\$ 730$ million per year. But, this is not being utilised properly due to various hurdles. One of the major obstacles is financing of these EE projects. Most financial institutions are not familiar with the aspects of EE projects. Also, weak credit strength of Energy Service Company (ESCOs) and perceived lack of collateral or guarantees also hinder the implementation of such projects. Added to this, financial institutions lack the appraisal capacities required for these projects. In this paper, appraising of EE projects is discussed and the benefits of financing EE projects are highlighted. Also, the paper discusses certain schemes and policies that could be implemented in order to make these projects more attractive to the Financial Institutions. Five Basic methods of appraisal i.e. promoter appraisal, technical appraisal, financial appraisal, environmental appraisal and legal appraisal are necessary when it comes to EE projects. In addition, different perspectives of different stakeholders like Promoters, Lenders, Government, ESCOs, etc. are observed and understood in this paper. Also, the paper shall discuss in the detail about new financing mechanisms i.e. PRGF (Partial Risk Guarantee Fund) and VCF (Venture Capitalist Fund) and also along with ESCOs ability to benefit from these financing mechanisms.
\end{abstract}

Keywords Appraisal, Energy Efficiency, Energy Service Companies, PRGF, VCF

\section{Introduction}

\subsection{Background}

Energy Efficiency (EE) project refers to any process, technique or equipment that helps to achieve reduction in energy consumption to perform a designated operation to achieve same or better level of output while maintaining or improving processing time, quality, performance and safety with minimal environmental impact.

The development objective of the Energy Efficiency Project is to increase the demand for and competitive supply of energy efficient goods and services, contributing to

A. Increased efficiency of energy use

B. Lower vulnerability of corporates to the daily fluctuating energy prices

C. Reduced reliance of the Indian economy on imported energy and fuels

D. Reduced need for investment in newer power plants

E. Reduced emission from the energy sector

As per the Energy Efficiency Service Limited (EESL) an ESCO promoted by Government of India the energy efficiency market in India is around USD 15 billion, but only $5 \%$ of market is been tapped by ESCOs. In order to accelerate the implementation of energy efficiency projects it is very important to leverage the ESCO model. ESCOs in India are facing regulatory, institutional and financial barriers. Despite various efforts made by various institutions and bodies like BEE (Bureau of Energy Efficiency) and EESL, there are still challenges for ESCOs in India

But, looking at the rising trend of fuel costs and energy security concerns, it is time to leverage the opportunities available for upscaling the energy efficiency project implementation by ESCOs model. To tap these opportunities, governmental institutions and various financial institutions have to play a very significant role. 
For instance, in countries like China and Brazil the ESCOs are getting tremendous support from the government and also the ESCOs have established ESCO association while there is no such institution developed in India.

It is to be recognised that there is a difference between the appraisal for energy efficiency projects and conventional project. Both cannot be evaluated with the same principles and thus there is a necessity to understand the characteristic of EE projects,

\section{Basic Characteristic of EE Projects}

- Wide range of technologies, most with substantial experience with successful implementation, internationally as well as in India

- Relatively small project size - 10 Lakhs to 100 Crores

- $\quad$ Relatively short simple payback periods - generally one to five years

- $\quad$ High proportion of project development costs

- Range of implementation business models with increasing interest in performance based approaches

- Manageable risks.

\subsection{Different Stakeholders Involved}

The various Stakeholders of EE projects are

A. Project Company

B. Sponsors

C. Lenders

D. Government

E. EPC/ESCO Contractor

F. Academia

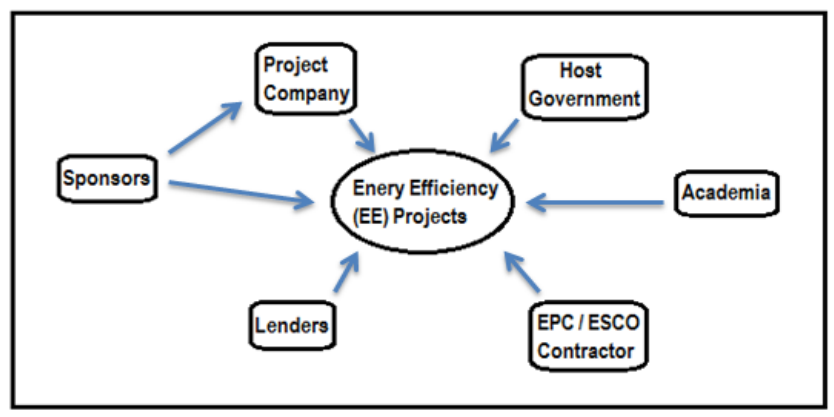

Figure 1. Different Stakeholders

\subsection{Difference between EE projects \& Conventional projects}

Energy Efficiency Projects and Conventional Project (e.g. Infrastructure) are different categories of projects and have different characteristics. Below are few points of difference between the two types of projects.
Table 1. Difference between EE Projects \& Conventional Infrastructure Projects

\begin{tabular}{|c|c|}
\hline Energy Efficiency Projects & $\begin{array}{c}\text { Conventional Infrastructure } \\
\text { Projects }\end{array}$ \\
\hline $\begin{array}{l}\text { Scale of Investments are low } \\
\text { (INR 0.2-2 Crores) }\end{array}$ & $\begin{array}{l}\text { Scale of Investment are very high } \\
\text { (INR 25-1000 Crores) }\end{array}$ \\
\hline $\begin{array}{l}\text { The projects characteristics are } \\
\text { not well understood by the } \\
\text { financial institutions }\end{array}$ & $\begin{array}{l}\text { Well-developed understanding } \\
\text { among financial institutions }\end{array}$ \\
\hline $\begin{array}{l}\text { No revenue realization (Cash } \\
\text { flow are improved due } \\
\text { reduction in operational costs) }\end{array}$ & $\begin{array}{c}\text { Revenue realization is there in case } \\
\text { of various infrastructure projects } \\
\text { ( Toll for Highways) }\end{array}$ \\
\hline $\begin{array}{l}\text { Special expertise are required } \\
\text { for appraising apart from } \\
\text { general understanding of } \\
\text { finance }\end{array}$ & $\begin{array}{l}\text { Special expertise in not required to a } \\
\text { great extent }\end{array}$ \\
\hline $\begin{array}{l}\text { SPV are not created here for the } \\
\text { projects }\end{array}$ & $\begin{array}{l}\text { SPVs are mostly created here for the } \\
\text { project financing purposes }\end{array}$ \\
\hline Low gestation periods & Very long gestation periods \\
\hline Technical risks are very high & $\begin{array}{c}\text { Technical risks are low compare to } \\
\text { EE projects }\end{array}$ \\
\hline $\begin{array}{l}\text { Special appraising techniques } \\
\text { ( Technical appraisal) required }\end{array}$ & $\begin{array}{c}\text { Conventional appraising techniques } \\
\text { are used }\end{array}$ \\
\hline $\begin{array}{l}\text { Examples of EE projects are } \\
\text { 1. } \quad \text { Bachat Lamp Yojana } \\
\text { 2. Ag DSM Schemes } \\
\text { 3. } \quad \text { Waste Heat Recovery } \\
\text { 4. } \quad \text { Lighting Africa }\end{array}$ & \begin{tabular}{ll}
\multicolumn{2}{c}{ Examples of Conventional Projects } \\
are \\
1. & \multicolumn{1}{c}{ Highway Projects } \\
2. & Airport Construction \\
3. & Thermal Power Projects \\
4. & Hydro Power Projects
\end{tabular} \\
\hline
\end{tabular}

\section{Sponsors \& Lenders}

\subsection{Profile of Sponsors}

Usually the EE Project sponsors can be classified into 4 major groups. Each of these customer segments calls for a different approach to business modelling, contracting and financing. Solutions should be embedded in the business structure and the contract

- Industrial Customers

- Government Customers

- Commercial Buildings

- Energy Service Companies (ESCOs)

\subsection{Profile of Lenders}

Lenders for EE projects are basically the banks (commercial, regional etc.) because the banks in India have a wider and deeper reach through its branches; approx. 67,000 branches and 300 banks. Below mentioned are the various types of banks, specialized lending institutions and schemes. 
- Commercial Banks

- Regional Rural Banks, Co-operative banks and credit societies

- Development Finance Institutions

- $\quad$ Specialized Banks

- Special Apex Financing Bodies:

- Government of India:

- Foreign Banks:

- Credit Default Guarantee Providers

Indian banks use its strong reach in rural areas to fund the priority sector like agriculture, SMEs etc. RBI and GoI have also encouraged incentive -led lending schemes for special purposes and sections of societies. Usually loans from these institutions are taken in the form of working capital and term finance. In case of EE projects in spite of availability of incentives like accelerated depreciation against income tax payable, leasing of assets is not popular in India and very few lenders are interested in providing financial support to EE projects in the form of leasing products.

\subsection{Barriers}

Though there is a presence of a well-established, robust network of banks and variety of schemes and incentives in India, still due to certain market barriers most banks refrain from lending to EE projects. These barriers are:

1 Lenders are unfamiliar with EE projects, lack of confidence in energy auditors, consultants and ESCOs and require technical support to appraise and manage lending to EE projects.

2 Technical risks are very high in EE projects so special technical appraisal

3 No sense of realized revenue stream (Savings are there)

4 Feasibility of the projects has to be assessed from different perspective i.e. improvement in cash flows for sponsors resulting from increased productivity and savings in energy cost

5 Multiple business model are there but very few of them are lender friendly

6 Not possible to standardize the single model that will be acceptable to various stakeholders

$7 \quad$ No scope for new market players as lenders prefer to lend their customers for their EE projects

8 Limited track records for ESCOs in building and managing the EE projects

9 No assurance of technical performance and aggressive monitoring of energy savings is to be needed

To overcome these barriers following criteria for designing EE financing products should be considered:

- New EE lending program should fit within conventional banking policy, systems and methodologies.
- $\quad$ EE project specific loan product should be capable of being scaled up, replicated by any other bank in the country with minimal external intervention, and decentralized so that it can be applied to varied business situations.

- Facilitate commercialization of loan schemes so that it can satisfy the commercial goals of the lender. Non-conventional features and short term incentives given at the initial stage to $\mathrm{EE}$ products are inappropriate and cannot be sustained beyond the govt. intervention period.

- Classification of loan as priority sector loans.

- Lenders should target specific customers such as SMEs.

- Use of Innovative financing mechanism such as Partial Risk Guarantee Funds (PRGF) and VCF (Venture Capital Funds)

\section{Appraising EE Projects}

After the submission of the loan application form, a bank would formally register the application and send a copy to relevant credit department in the bank for a detailed project appraisal, which would be followed by these:

- Promoter Appraisal

- Technical Appraisal

- Financial Appraisal

- Environmental Appraisal

- Legal Appraisal

\subsection{Types of Appraising for EE Projects}

\subsubsection{Promoter Appraisal:}

Promoter appraisal is done only for new customers. It is done to basically ascertain the promoter/promoter company/companies background, creditworthiness, track record, and their past dealings with institutions and banks. An indicator checklist to facilitate promoter appraisal is given below:

\section{General}

- Memorandum and Articles of Association (for new customer)

- Promoters' agreement

- Obtain and study the corporate plan of the company (for small projects, only if corporate plan is available)

- Particular of other projects promoted/implemented by promoter in the particular industry (to understand the promoters' track record in project execution)

- References from company's bankers/other lenders (applicable for new customers)

- Information of bank limits utilized, future business plans and investments to be examined

- Group companies, their operations and the banks' exposure/experience 


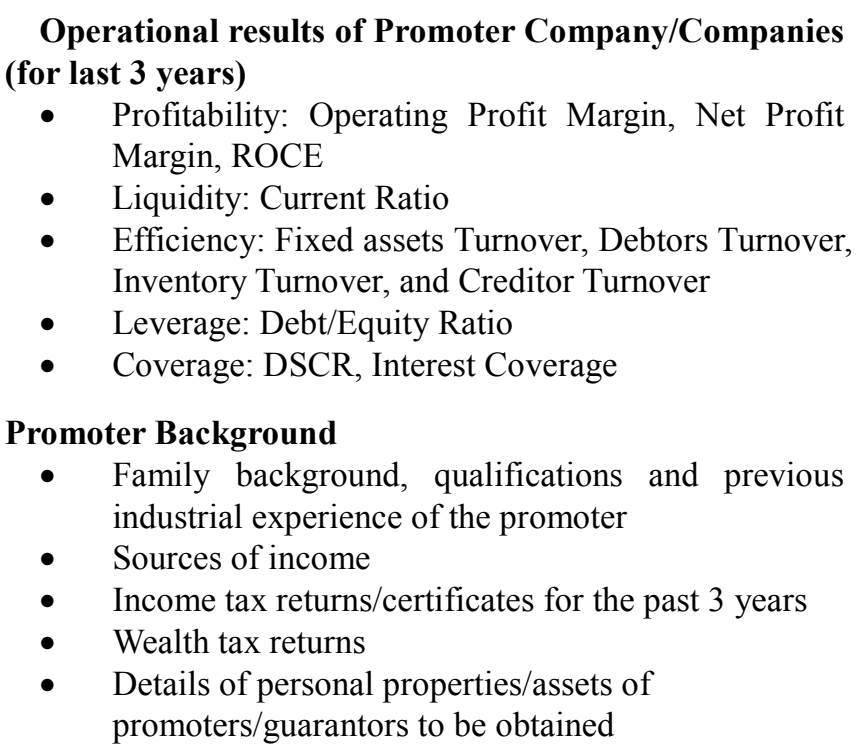

Management and Organizational setup of Promoter company/Companies

- Details of Board of Directors

- Number of full time directors and their responsibilities

- Qualification, experience and competence of functional executives

\subsubsection{Technical Appraisal}

Technical Appraisal of an EE project primarily focuses on three fundamental issues:

- Are the projected energy savings realistic? Is the basis of calculation appropriate?

- Which technology will be used for the EE project, and whether it fits with the existing technology/processes at the facility?

- Are there any drawbacks like impact of production or production schedules during implementation of the project?

Overall the evaluation parameters for technical appraisal of an EE project have been classified into three categories:

1) Estimating Energy Savings : Energy Savings = Baseline Energy Consumption - Energy Consumption post EE Implementation +/-Adjustments

2) Technology Evaluation: Focus on the appropriate technology and compatibility of the technology with the existing technology or process in a given facility.

3) Proposed Project Implementation Plan

Key Difference in Technical Appraisal (EE Project Vs. Conventional Project)

Energy Savings Estimation: Technical Appraisal of an EE project reviews the process used to compute the energy savings, and assess how realistic the energy savings are?

\subsubsection{Financial Appraisal}

Financial Appraisal of an EE project would review the below mentioned parameters.

\section{1) Project Cost}

For small and medium sized EE projects, hardware costs, which comprises of the equipment, spares, and tools typically constitute a majority $(65-75 \%)$ of the total project cost. The remaining (25-35\%) project costs are soft costs, which include the energy audit charges, consultancy fees and project management charges (incl. charges for design and engineering). The main components of project cost and key issues to be considered during appraisals are:

- Pre-operative and Preliminary Expenses - These expenses include

(a) Cost of conducting energy audits, and

(b) Cost of preparing project feasibility reports

- Equipment Cost - It should be based on quotations/purchase contracts entered into between the applicant and the suppliers. In cases where EE project is executed by ESCO/EPC the contract may be entered between the ESCO/EPC and the supplier.

- Design and Engineering Fees, and Project Implementation Charges

- Interest during Construction Period - It refers to an amount equivalent to the interest and other charges payable by the borrower to the bank at an agreed rate during the construction period of the project. The interest during construction period should be capitalized and included in the cost of EE project.

- Contingencies - 5 to $10 \%$ of project cost as contingencies or such percentage in accordance with the internal guidelines of the bank.

For large EE projects and co-generation projects, project cost components may also include the following cost heads, as applicable over and above those components are:

- Cost of land and building

- $\quad$ Plant and machinery cost

- Technical know-how expenses

- Miscellaneous Fixed Assets like furniture, office equipment, tools, vehicles etc.

\section{2) Means of Financing}

Some of the important sources of finance for an EE project are as follows:

- Promoter's Contribution- In the form of:
a) Equity - share capital or unsecured loans from promoters/associates
b) Internal accruals from the existing companies

As a rule of thumb, minimum promoters' contribution of $20 \%$ of the project cost is recommended.

- Term Loans - In case the project is to be funded by a consortium of lenders, it should be ensured that 
the other expected sources of loans are properly tied up, since any gap in the project funding will adversely affect the project.

- Others - Government subsidy/grants may be available for certain kinds of EE projects. Since these funds are normally realised at the end of the project or after commencement of the operations, it is necessary to stipulate a condition that the promoters would bring in their own funds to bridge the gap until such time the government funds are received.

\section{3) Profitability Projections/Project Cash flow}

Profitability estimates, projected cash flow and balance sheet should be prepared for both the specific EE project(s) and the company as a whole. The projections should cover the entire duration of the loan. The bank should scrutinise the financial projections with reference to cost of the EE project, means of financing and assumptions made in respect of schedule of implementation, capacity utilisation, energy savings and operating expenses. Key assumptions of profitability projections of an EE project are as follows:

- Capacity Utilisation

- $\quad$ Estimated Energy Savings

- $\quad$ Operating, maintenance and repair (OM\&R) expenses

For Cash Flow projections for an EE project, please refer to Annexure

\section{4) Financial Viability Parameters}

The viability parameters recommended for EE projects could be divided into:

- Key financial parameters: include Internal Rate of Return (IRR), Debt Service Coverage Ratio (DSCR), Debt-Equity Ratio, and Asset Coverage Ratio.

- Other financial Parameters: Payback Period, Interest Coverage Ratio, and Net Cash Accrual Ratio.

Key Difference in Financial Appraisal (EE Project Vs. Conventional Project)

Basis of Project Cash flow: In an EE project cash flow is based on projected energy savings (improvement in bottom-line), unlike in a conventional project where cash flow is based on financial projections of top and bottom line.

\subsubsection{Environmental Appraisal}

Asses the pollution level of the given facility post EE project implementation, and compare the same with the level pre-implementation of the EE project.

- Government Notification (MoEF):

"expansion or modernisation of any activity if pollution load is to exceed the existing one, or new project listed in schedule I to this notification, shall not be undertaken in any part of India unless it has been accorded environmental clearance by the Central Government"

\subsubsection{Legal Appraisal}

Prior to disbursal of loan, the bank should ensure that all necessary legal documentation is completed. An indicative checklist of approvals and documentation required is given below:

- Statutory Approvals - Environmental Clearance from Ministry of Environment and Forest and State Pollution Control Board, if applicable.

- Legal Documentation - Sanction Letter or LOI, Loan Agreement, Due-diligence of security package

- Due-diligence of agreement with supplier

- Due-diligence of performance contract

\subsubsection{ESCO Appraisal}

An Energy Savings Company (ESCO) is a company that is engaged in developing, installing and financing performance-based projects, aimed at energy efficiency or load reduction of facilities owned/operated by customers. It offers the customer a single window to address all areas of energy efficiency. Typically, an ESCO offers the following EE services:

- Energy audit and formulation of detailed project reports

- Implementation of $\mathrm{EE}$ projects (includes undertaking implementation and project monitoring)

- Procurement of equipment to be installed

- Arranging finance for the project in select cases

- Equipment maintenance and operations

Performance Contract

An ESCO may enter into a performance contract with the customer to guarantee a certain amount of energy savings from the project or a shared savings basis.

Types of Performance Contracts

- Guaranteed Savings: ESCO guarantees a certain level of energy savings to be achieved from executing the EE project. If the guaranteed savings are not achieved, ESCO covers the difference between the guaranteed savings and the actual savings.

- Shared Savings: Customer commits to pay only a percentage of the realized savings to ESCO for cost of designing, implementing and monitoring the energy efficiency project. Here, the customer assumes no financial obligation other than to pay the ESCO a share of savings that the project realizes.

An ESCO could approach a bank for financing in the following two ways:

- Credit Line to ESCO: An ESCO could seek a credit facility from the bank to finance its current operations, which may include financing ongoing or future projects. The credit facility may not be a project specific, and the ESCO may be allowed to draw down the facility whenever required until the 
expiry of the facility. A facility may be a revolving or terminating line.

The appraising methodology to be used for such financing would be based on the promoter appraisal mechanism as explained under type of appraisal mechanism.

- Project-specific financing to ESCO: An ESCO could seek finance for a specific energy efficiency project, which the project is executing. The appraising methodology to be used for such financing would be as follows:

- Assess its ability to successfully execute and maintain the EE project. This can be divided into:

a) Basic Information: Track Record, Firm Structure, Qualifications \& Experience, Financial Information.

b) Client Reference Checks: At least 3 client references preferably from that particular industry, for projects completed within the last two years are required

\section{Stakeholder Perspective of EE Projects}

\subsection{Appraisal Criteria from stakeholder perspective}

Appraisal of the project is not only important from lenders point of view but needs to appraise considering the interest of all the stakeholders involved in the project. Each stakeholder has different expectation from the project and need to appraise considering the expectation of all. Following section will give the detail appraisal indicators which need to be considered for various stakeholders involved.

\subsubsection{Promoters Perspective}

Table 2. Indicators and Importance from Promoters Perspective

\begin{tabular}{|c|l|}
\hline Indicators & \multicolumn{1}{c|}{ Importance } \\
\hline $\begin{array}{c}\text { Average Annual } \\
\text { Energy Savings }\end{array}$ & $\begin{array}{l}\text { From this, the promoters are able to calculate } \\
\text { the cost reduction due to the savings. }\end{array}$ \\
\hline Profit Margin & $\begin{array}{l}\text { Here, it helps the promoter to find whether } \\
\text { there is any change in the bottom line after } \\
\text { implementing the project. }\end{array}$ \\
\hline Cash Flow & $\begin{array}{l}\text { It helps in determining any improvements in } \\
\text { the cash flow due to the EE project. }\end{array}$ \\
\hline Payback Period & $\begin{array}{l}\text { It helps in calculating the time period within } \\
\text { which the investments can be recovered. }\end{array}$ \\
\hline $\begin{array}{c}\text { Specific Energy } \\
\text { Consumption }\end{array}$ & $\begin{array}{l}\text { From this, they can determine how efficient } \\
\text { the processes have become. }\end{array}$ \\
\hline $\begin{array}{c}\text { Representation \& } \\
\text { Warrantees by } \\
\text { ESCOs }\end{array}$ & $\begin{array}{l}\text { Project being implemented in accordance } \\
\text { with energy audit report, necessary } \\
\text { professional skills and adequate resources to } \\
\text { undertake the project. }\end{array}$ \\
\hline
\end{tabular}

Promoters' perspective of the project appraisal for EE projects is always important as they are the ones who would ultimately reap the benefits or losses on implementing the EE project.

\subsubsection{Lenders Perspective}

Lenders' perspective of the project appraisal is critical as this helps them decide whether the project is commercially viable or not.

Table 3. Indicators and Importance from Lenders Perspective

\begin{tabular}{|c|c|}
\hline Indicators & Importance \\
\hline Evaluation & $\begin{array}{c}\text { The lenders need to do this evaluation in } \\
\text { order to predict the viability of the project. }\end{array}$ \\
\hline Income Distribution & $\begin{array}{c}\text { It helps determining in how income can be } \\
\text { generated with the help of the EE project }\end{array}$ \\
\hline Debt-Equity Ratio & $\begin{array}{c}\text { The amount of equity and debt taken by the } \\
\text { project company. }\end{array}$ \\
\hline DSCR & $\begin{array}{c}\text { It tells the lenders about the interest paying } \\
\text { capacity of the company after the EE } \\
\text { project is implemented }\end{array}$ \\
\hline IRR & $\begin{array}{c}\text { The rate of return expected due to the } \\
\text { implementation of the project }\end{array}$ \\
\hline $\begin{array}{c}\text { Credibility of the ESCO } \\
\text { Creditworthiness of the } \\
\text { company }\end{array}$ & $\begin{array}{c}\text { It tells whether the ESCO has done any } \\
\text { implemented such project previously } \\
\text { whether the company can actually repay the } \\
\text { debt amount. }\end{array}$ \\
\hline Interest Coverage Ratio & $\begin{array}{c}\text { It is an indicator of the interest } \\
\text { serviceability of the company }\end{array}$ \\
\hline $\begin{array}{c}\text { Legal Requirements and } \\
\text { Guarantee Facility }\end{array}$ & $\begin{array}{c}\text { Intended to mitigate credit default risk } \\
\text { resulting from technical failure and security } \\
\text { related conflicts. }\end{array}$ \\
\hline
\end{tabular}

\subsubsection{ESCO Perspective}

ESCOs' perspective of the project appraisal for EE projects is crucial as it helps in finding the possibility of success on obtaining energy savings

Table 4. Indicators and Importance from ESCOs Perspective

\begin{tabular}{|c|c|}
\hline Indicators & Importance \\
\hline $\begin{array}{c}\text { Energy Service } \\
\text { Agreement }\end{array}$ & $\begin{array}{c}\text { Type, Terms, Remedies for consequences, } \\
\text { termination of the contract decides the fate } \\
\text { of the EE project. }\end{array}$ \\
\hline $\begin{array}{c}\text { Representation and } \\
\text { warrantees by project } \\
\text { sponsors }\end{array}$ & $\begin{array}{c}\text { Provision of facilities to the ESCO during } \\
\text { the time of implementation of the project } \\
\text { and extend necessary support during } \\
\text { project implementation. }\end{array}$ \\
\hline Compensation Model & $\begin{array}{c}\text { Guaranteed savings model/ Shared } \\
\text { Savings Model }\end{array}$ \\
\hline Insurance Coverage & $\begin{array}{c}\text { Extent to which the insurance is covered } \\
\text { by the project company }\end{array}$ \\
\hline Payment Structure & $\begin{array}{c}\text { Creation of a sound payment structure to } \\
\text { ensure proper cash flows for both the } \\
\text { ESCO and the project company }\end{array}$ \\
\hline
\end{tabular}

\subsubsection{Risk Associated with EE projects}

Five level of analysis from Standards \& Poor's framework for project analysis

- $\quad$ Project Level Risks

- $\quad$ Sovereign Risks

- $\quad$ Business and Legal Institutional Development Risks

- $\quad$ Force Majeure Risks

- Credit Enhancement 


\section{New Financing Options for EE Projects}

Under the National Mission for Enhanced Energy Efficiency (NMEEE), a financing platform has to be developed in order to finance the energy efficiency activities. For this a Venture Capital Fund (VCF) and a Partial Risk Guarantee Fund (PRGF) along with innovative financial derivatives of performance contracts and fiscal and tax incentives for investment in this sector are sought to be established. Government has announced an amount of INR 75 Crore (USD 16.5 Million) and 95 Crore (USD 21.5 Million) to be earmarked for VCF through the budget during the previous and the current financial year. The VCFEE is designed to be a revolving fund.

In order to overcome the hurdles towards financing the EE projects as discussed in previous sections, BEE (Bureau of Energy Efficiency) has come up with two innovative mechanism for financing EE projects. These mechanisms are at very nascent stage and it would take time for these mechanisms to mature and get accepted in the market. The project developer/ project sponsor could leverage such schemes to effectively finance such projects from bank and other institutions. In the following section two of the innovative mechanism are been discussed i.e. PRGF (Partial Risk Guarantee Fund) \& VCFEE (Venture Capital Fund for Energy Efficiency).

\subsection{Partial Risk Guarantee Fund (PRGF)}

Today bankers are faced with the risk of the defaults and are very sceptic about EE projects because of the complexity involved in financing such projects. Thus to leverage commercial financing, as a part of NMEEE, Government of India has operationalize PRGF with BEE give the task of managing the funds.

PRGF is a risk sharing mechanism, under which the risk borne by the financial institutions are reduced, as the risk also borne by the issuer of PRG i.e. GoI. Under this scheme the guarantee is provided to commercial banks with partial coverage of risk exposure against loans made for energy efficiency projects to mitigate the risk perception associated with the lending for new technologies and new business models associated with energy efficiency projects. The risk covered by the project is mainly credit risk and the transaction involved in financing such projects, the risk cover is up to $50 \%$ of the debt. PRGF can acts as instrument to overcome various barriers by providing the easy and less costly access to finance and also by reducing the cost of capital (WACC) and extending loan tenure by to match the project cash flows.

The PRGF will act as a first loss, subordinated recovery guarantee and will be placed in a guarantee reserve account and will be paid out to participating banks in the event of a loss or default. The amount paid out will be equal to the amount of outstanding principal times the guarantee percentage, and will not cover accrued interest or other fees owed to the bank. The lending banks will also pursue recovery procedures in the event of default, and will pay to PRGF any monies recovered after first satisfying its own receivables

The guarantee would maximum cover Rs 3 Crores or $50 \%$ of the project cost (Whichever is less) in case of the default it covers loss subject to maximum of $10 \%$ of guaranteed amount and remaining is shared on Pari-Passu (Equally) basis. The table mentioned below shows the simple PRGF mechanism

Table 5. PRGF Mechanism

\begin{tabular}{|c|c|c|c|}
\hline \multicolumn{4}{|c|}{$\begin{array}{l}\text { Suppose the project cost is Rs } 1 \text { Crores, the guarantee is provided on Rs } \\
50 \text { Lakhs }(50 \%)\end{array}$} \\
\hline $\begin{array}{l}\text { Default } \\
\text { Amount }\end{array}$ & $\begin{array}{c}\text { Shared by } \\
\text { Bank }\end{array}$ & Shared by PRGF & $\begin{array}{l}\text { Shared on } \\
\text { Parri Passu }\end{array}$ \\
\hline $\begin{array}{l}\text { Rs. } 2 \\
\text { Lakhs }\end{array}$ & Rs. 0 & Rs 2 Lakhs & Rs. 0 \\
\hline Rs 5 Lakhs & Rs.0 & Rs. 5 Lakhs & Rs. 0 \\
\hline Rs 8 Lakhs & $\begin{array}{l}\text { Rs. } 1.5 \\
\text { Lakhs }\end{array}$ & $\begin{array}{l}\text { Rs. } 5 \text { Lakhs and Rs } 1.5 \\
\text { Lakhs (Parri-Passu) }\end{array}$ & Rs. 3 Lakhs \\
\hline
\end{tabular}

Such fund could be very useful to financing the EE projects aimed at improving the energy usages in various sectors and could be even use to finance projects under Ag DSM and $\mathrm{Mu}$ DSM schemes which are facing lack of participation from private sector because of risk associated with the projects.

Because of such mechanism the ESCOs could have an advantage as the financing of EE projects could become easier. In countries like China and European countries have initiated such schemes and have witnessed considerable participation from various private financial institutions.

\subsection{Venture Capital Fund (VCF)}

VCFEE is established to promote the manufacturing of energy efficient equipments which are usually perceived to be high risk in the market and to be a source of last option equity for any EE projects limited to $15 \%{ }^{1}$ of its total value. To decide the structure of VCFEE, an international survey was conducted to find and study similar mechanism implemented elsewhere in the world. Finally, in consultation with BEE, three different institutional structure options were considered. These are:
i. VCFEE managed by BEE
ii. VCFEE managed by an Independent Trust
iii. VCFEE managed by a Venture Fund Manager which has an MoU with BEE

Finally, it was suggested that a VCFEE managed by an Independent Trust (option 2), constituting representatives from various contributors, with an investment committee and a professional fund manager, is the best option as it brings strengths at all levels in the structure - monitoring of

1 Bureau of Energy Efficiency (VCFEE): https://beeindia.gov.in/content/vcfee 
the fund by trustees; financial and technical expertise of Investment committee; and knowledge of a fund manager. Particularly, when the fund will grow larger with other donors joining in, this option will seem more viable, providing the flexibility to grow with lesser institutional changes and lower associated operational costs.

Energy efficiency, being a niche category of projects, will attract investors who has an experience in executing such projects or who has invested into similar projects and got positive results. What is more important here is to make the potential donors understand the difference in the $\mathrm{RoE}$ pattern of an EE project and a conventional project. While conventional projects needs high investment, has a long gestation period $(8-10$ years) with high returns, EE projects usually needs less capital, has a short gestation period (returns can be realized as early as 6 months to a maximum of 4 to 5 years) with comparatively less returns. The advantage of EE projects over the conventional project is that it does not lock in the funds for a long period and hence, the money keeps on circulating faster in the market and can reach to more number of projects. Also, chances of complete failure of an EE project are minimal compared to conventional projects as any EE project is based on need of a company for its own i.e. it comes into existence because inefficiencies are found. A technically sound auditor can accurately predict the savings and hence, returns from an EE project. In a nutshell, there are very less chances that VC donors will incur loss. It's just a matter of time that a few successful cases will start attracting more and more projects in this sector.

VCFEE has been formed keeping in mind certain opportunities where this fund can easily come into handy. It can provide finance to potential ventures at two levelscompany level and project level.

At company level, it can fund into following 3 major categories:

1) Incubation \& Expansion of new Energy Efficiency technology: e.g. Equity investments in companies with promising new technologies (such as LEDs) that offer significant potential for energy efficiency.

2) Technology Transfer leads to manufacturing: e.g. technology transfer for an energy efficiency technology.

3) New business models based on old/new/multifold EE technology: e.g. Energy Service Companies (ESCOs) which offers performance contracts and have technical capabilities of engineering.

At Project level, the fund can be utilized in the following way:

1) "Last Mile" equity support for public sector projects: equity support to public sector projects such as municipal level energy efficiency. Maximum funding provided could be $25 \%$ of total project cost or $50 \%$ of total equity required, whichever is lower.

\section{ESCO Relevance}

Today, in India ESCOs are facing a lot of problem with respect to implementation of EE projects. Theoretically, the potential of ESCO is enormous in India still ESCOs in India are facing barriers against growth. Despite various efforts made by various institutions and bodies like BEE (Bureau of Energy Efficiency) and CII (Confederation of Indian Industry), there are still threats to the future of ESCOs in India. But, looking at the rising trend of fuel costs and energy security concerns, it is time to leverage the opportunities available for ESCOs. To tap these opportunities, governmental institutions and various financial institutions have to play a very significant role. For instance, in countries like China and Brazil the ESCOs are getting tremendous support from the government and also the ESCOs have established ESCO association while there is no such institution developed in India.

While implementing EE projects, role of ESCOs is similar role to that of a project developer, yet they have different risk profiles. ESCOs tend to put less equity in EE projects and most of the finances comes from long term debt or credit to the end-user, backed by the reputation of the ESCO and, more importantly, a strong contract with the end-user.

The important factor in financing an EE project is the creditworthiness of the company where the project has to be executed. But, for these projects there is often little or no collateral provided. Hence, while sanctioning the loan, the banks, leasing firms, vendors have to rely on the ESCO. There is a high probability of getting finance if the ESCO which is handling the project has a proven track record for handling such projects. Also, in addition to the realization of savings, the strength of the contract between the ESCO and its customer and the willingness of the end user to pay also pay a considerable part in getting the finance. 


\begin{tabular}{|c|c|}
\hline Barriers & Solution \\
\hline Technical Competency & $\begin{array}{c}\text { Strengthening technical competency by: } \\
\text { Various programs for capacity buildings } \\
\text { Tie up with Academia } \\
\text { Preparing Standard guidelines for technical evolution for EE } \\
\text { projects } \\
\text { Need of Project Management Approach for Implementing EE } \\
\text { projects } \\
\text { Formation of ESCOs association }\end{array}$ \\
\hline Appraising EE Projects & $\begin{array}{c}\text { Appraising EE projects is different from conventional } \\
\text { appraising } \\
\text { Adopting Proper Technical Appraisal Methodology } \\
\text { Adopting Cash Flow approach for evaluation of EE projects } \\
\text { Large EE Projects like BLY, Ag DSM should be evaluated on } \\
\text { Equator Principle }\end{array}$ \\
\hline Lack of Clarity on Business Model for EE Projects & $\begin{array}{c}\text { There is need of providing proper knowledge of models that } \\
\text { could be adopted for EE projects } \\
\text { Guaranteed Savings } \\
\text { Shared Saving Model } \\
\text { Need of Standardization on a single structure }\end{array}$ \\
\hline Financing EE projects & $\begin{array}{c}\text { There is need of Innovative Financing Mechanism for EE } \\
\text { projects } \\
\text { Leveraging PRGF mechanism } \\
\text { Leveraging VCFEE mechanism } \\
\text { Payment through ESCROW account }\end{array}$ \\
\hline High Development Cost for EE projects & $\begin{array}{c}\text { Governmental Support in form of } \\
\text { Tax Rebate } \\
\text { Service Tax Exemption on Audit } \\
\text { Depreciation Benefits } \\
\end{array}$ \\
\hline Other issues & $\begin{array}{c}\text { Insurance Coverage } \\
\text { Transparent and ESCO friendly Payment Structure } \\
\text { Credit Guarantee } \\
\text { Need of Standardized Contract }\end{array}$ \\
\hline
\end{tabular}

\section{Recommendations}

1. For financial development of large scale energy efficiency projects "Equator Principle" should be used, which are set of guidelines developed for managing social and environmental issues. This principle can also be used for appraising various infrastructure projects in India. Some banks who promote this principle are $\mathrm{ABN}$ Amro Bank, Deutsche Bank, Barclays PLC, Citi Bank etc. This might attract the foreign lenders to provide funds for EE projects in India

2. ESCROW model should be used more aggressively to promote the energy efficiency projects from the promoters' perspective keeping in mind the interests of the ESCOs/Project Contractor.

3. A PRGF is a risk sharing mechanism lowering the risk to the lender by substituting part of the risk of the borrower by granting guarantee ensuring repayment of part of the loan upon a default event hence, it can be leveraged very effectively for EE projects.

4. The VCF donors should be made used to the revenue realization pattern of the energy efficiency projects i.e., low investment, short gestation period with comparatively lower returns.

5. In case of small projects where it is not possible to get VCF, provisions should be made to allow for grouping and consolidation of these projects, and to allow VCF to be considered for the consolidated project

\section{REFERENCES}

[1] Padamlatha Suresh, Project Finance: Concepts and Applications, IUP Publications

[2] Prasanna Chandra, Projects : Planning, Analysis, Selection, Financing, Implementation and Review, McGraw Hill Publications

[3] Saurabh Didi, Innovative Financial Mechanism, Bureau of Energy Efficiency

[4] Energy Efficiency Service Limited: http://www.eeslindia.org /User_Panel/UserView.aspx?TypeID=1025

[5] Appraising Energy Efficiency Projects : Designing Financial Structure and Instruments, IREDA (Manual)

[6] Formulation, appraisal and approval of plan schemes and projects compendium of important circulars, Government of India ,Ministry of Finance ,Department of Expenditure Plan Finance II Division

[7] Valavan V T and Bhatia D, Key results of studies carried out under 3-country Energy Efficiency Project of World 


\section{Bank/UNEP/UNF}

[8] The ESCO concept in the Indian scenario, from: www.energymanagertraining.com/Journal

[9] Venture Capitalist Funds for Energy Efficiency: https://beeindia.gov.in/content/vcfee
[10] Investors Manual for Energy Efficiency, IREDA and CII

[11] Manual to Appraise Energy Efficiency, Project, IREDA and ICRA

[12] Quarterly Research note No.14, 2011: Can ESCOs drive energy efficiency in urban services?, IDFC 